\title{
Amphetamine-Induced Dopamine Release and Post-Synaptic Specific Binding in Patients with Mild Tardive Dyskinesia
}

\author{
Caleb M. Adler, M.D., Anil K. Malhotra, M.D., Igor Elman, M.D., David Pickar, M.D., \\ and Alan Breier, M.D.
}

Several lines of evidence suggest that changes in dopamine release and/or post-synaptic sensitivity may be involved in the pathogenesis of tardive dyskinesia (TD). Preclinically, increased $D_{2}$ receptor sensitivity and dopamine turnover are associated with $D_{2}$ receptor antagonism. Clinically, development of $T D$ is associated with $D_{2}$ receptor antagonist administration. Eight patients with mild evidence of TD (AIMS ratings $\geq 14$ ) and six without $($ AIMS $=10)$, underwent $\left[{ }^{11} C\right]$ raclopride PET scans. Baseline and amphetamine-induced decrements in striatal specific binding were assessed. Baseline and amphetamineinduced decrements in specific binding did not differ between patients with and without evidence of mild TD $(p=.53)$. AIMS ratings did not significantly correlate with baseline ( $p=.76)$ or decrements in specific binding ( $p=$ .45). This study provides evidence that TD is not associated with increased amphetamine-induced presynaptic dopamine release and/or $D_{2}$ receptor binding as measured by $\left.{ }^{[11} \mathrm{C}\right]$ raclopride PET. More research is needed to unravel the neurobiology of this debilitating disorder.

[Neuropsychopharmacology 26:295-300, 2002] (C) 2002 American College of Neuropsychopharmacology. Published by Elsevier Science Inc.
KEY WORDS: Tardive dyskinesia; Amphetamine; Striatum; Dopamine; Raclopride; PET

Tardive dyskinesia (TD) is a debilitating and frequently progressive movement disorder of unclear provenance (Jimenez-Jimenez et al. 1997; Cardoso and Jankovic

From the Experimental Therapeutics Branch, National Institute of Mental Health, NIH, Bethesda, MD. CMA is now at the Bipolar and Psychotic Disorders Research Program, Department of Psychiatry, University of Cincinnati College of Medicine, Cincinnatti, $\mathrm{OH}$; AKM is now at the Unit of Molecular Psychiatry, Hillside Hospital, New Hyde Park, NY; IE is now at the Department of Psychiatry, Massachusetts General Hospital, Boston, MA; DP is now at Comprehensive NeuroScience, Inc., Washington, DC; and AB is now at Lilly Research Laboratories, and Indiana University School of Medicine, Department of Psychiatry, Indianapolis, IN.

Address correspondence to: Caleb M. Adler, M.D., Department of Psychiatry, University of Cincinnati, College of Medicine, 231 Albert Sabin Way, Cincinnati, Ohio 45267-0559.

Received 8 February 2001; revised 7 June 2001; accepted 2 July 2001.

Online publication: 7/5/01 at www.acnp.org/citations/ Npp070301144.
1997) that occurs in approximately $20 \%$ of schizophrenic patients treated with neuroleptics (Kane and Smith 1982; Morgenstern and Glazer 1993; Jeste and Caligiuri 1993) but may occur in any population receiving medications that antagonize the $\mathrm{D}_{2}$ receptor (Jeste and Caligiuri 1993). Manifestations of TD may include orofacial movements, axial movement, and limb flexion/extension, as well as opisthotonos and tardive tremors (Cardoso and Jankovik 1997).

Despite the significant clinical impact of TD, the etiology of the phenomenon has not been substantially elucidated. Several lines of evidence suggest that TD is related to increased receptor binding sensitivity in the basal ganglia, stemming from long-term $\mathrm{D}_{2}$ receptor blockade by neuroleptics (Klawans 1973). Administration of $\mathrm{D}_{2}$ blocking agents induces an increase in striatal $\mathrm{D}_{2}$ receptor density (Burt et al. 1977; Clow et al. 1979; Owen et al. 1980) and dopamine turnover in rodents (Clow et al. 1978, 1979), as well as an increase in $\mathrm{D}_{2}$ re- 
ceptor sensitivity to indirect dopamine agonists (Tarsy and Baldessarini 1974; Gianutsos and Moore 1977; Clow et al. 1978, 1979; Owen et al. 1980). Clinical observations also support suggestions that neurolepticrelated increases in $\mathrm{D}_{2}$ binding sensitivity may be involved in TD.

Manifestations of movement disorders in schizophrenic patients resembling TD may occur in the absence of neuroleptic medication, but are quite uncommon. Moreover, atypical antipsychotic medications with relatively little $\mathrm{D}_{2}$ blockade are generally associated with a lower incidence of TD (Meltzer et al. 1989; Meltzer and Gudelsky 1992; Casey 1997). In patients, acute withdrawal of neuroleptic medications may increase or unmask TD-like movements and addition of $\mathrm{D}_{2}$ receptor antagonists may temporarily blunt TD symptomatology, possibly by respectively exposing or blocking sensitized $\mathrm{D}_{2}$ receptors (Crane and Naranjo 1971; Cardoso and Jankovic 1997). Consistent with this model of TD, Silvestri et al. (2000) found increased $D_{2}$ binding potential with long-term exposure to antipsychotic medication. Further, on both post-mortem exam and structural imaging, TD has been associated with the presence of pathology of the basal ganglia (Campbell et al. 1985; Mion et al. 1991; Granholm et al. 1993).

Studies directly examining $\mathrm{D}_{2}$ receptor density in patients with TD however, have failed to support hypotheses that increased dopamine binding sensitivity is responsible for TD. Brains of schizophrenic patients with TD examined post-mortem have not demonstrated an increase in striatal $\mathrm{D}_{2}$ receptor density (Cross et al. 1985; Kornhuber et al. 1989). Similarly, two in vivo positron emission tomography (PET) studies using $\mathrm{N}-\left[{ }^{11} \mathrm{C}\right]-$ methylspiperone and $\left[{ }^{76} \mathrm{Br}\right]$-bromospiperone failed to demonstrate increased $D_{2}$ receptor density in individuals with TD, both compared with individuals exposed to neuroleptics without TD, and in a cohort of age matched controls (Blin et al. 1989; Andersson et al. 1990). A PET study examining patients with Parkinson's Disease also failed to find any difference in $\mathrm{D}_{2}$ receptor binding in patients who had developed dyskinesias (Turjanski et al. 1997). Moreover, although Blin et al. (1989) observed correlation between orofacial dyskinesia and $\mathrm{D}_{2}$ receptor density, no correlation between global dyskinesia and $\mathrm{D}_{2}$ binding was found.

Previous PET studies however, were not primarily constituted of schizophrenic or schizoaffective patients, raising issues of generalizability to these illnesses, particularly given the important role dopamine dysregulation is thought to play in schizophrenia and schizoaffective disorder. In addition, these studies examined only post-synaptic binding data. Schizophrenic patients have been hypothesized to exhibit decreased tonic striatal dopamine release and increased sensitivity to stimuli (Grace 1991), both of which may play a role in the pathogenesis of TD. Examining pharmacologically in- duced presynaptic dopamine release as well as baseline, post-synaptic binding is necessary to address this potential confound. Furthermore, previous studies have examined individuals with relatively advanced TD. Given the lack of understanding of the pathophysiology of TD, it may be important to study specific binding in subjects with milder symptomatology.

Others and we have previously used $\left[{ }^{11} \mathrm{C}\right]$ raclopride, a $\mathrm{D}_{2} / \mathrm{D}_{3}$ receptor ligand to measure striatal dopamine binding at baseline and with administration of pharmacological agents (Breier et al. 1997, 1998; Smith et al. 1998; Adler et al. 2000). Baseline $\left[{ }^{11} \mathrm{C}\right]$ raclopride binding provides a measure of relative baseline $D_{2}$ receptor binding sensitivity. Decreases in $\left[{ }^{11} \mathrm{C}\right]$ raclopride binding following administration of amphetamine, an indirect dopamine agonist, are proportional to striatal dopamine release. In this study we utilized $\left[{ }^{11} \mathrm{C}\right]$ raclopride PET to examine baseline and amphetamine-induced striatal $\mathrm{D}_{2}$ receptor binding in patients with early evidence of TD, and compared this group to a matched cohort of patients without evidence of movement disorder.

\section{METHODS}

\section{Subjects}

Fourteen patients (mean $\pm \mathrm{SD})($ age $=33.6 \pm 9.6,12$ males, three females) participated in this $\left[{ }^{11} \mathrm{C}\right]$ raclopride study. Patients were diagnosed with schizophrenia $(n=$ 10) schizoaffective disorder $(n=2)$, major depression $(n=$ $1)$, or bipolar affective disorder $(n=1)$. Patients were admitted to the $4 \mathrm{E}$ inpatient unit of the Clinical Center at the National Institutes of Health and, after evaluation to determine competency to provide informed consent, agreed to participate in this IRB-approved protocol. Patients participated in a weekly group meeting, which reviewed and addressed questions pertaining to the science and methodology of the current study and other studies being conducted on the unit.

DSM-III and IV diagnoses were made in a best estimate meeting and were based on clinical interview, the SCID-IIIR and SCID-IV (Spitzer et al 1990; First et al. 1997), past medical and psychiatric records, and informant interviews. Patients were in good health as determined by physical exam, screening blood work and ECG. Three patients were medication naive or had not received medication for greater than five years. The remainder was free of antipsychotic medications for a minimum of ten days (20.1 \pm 10.9 days). In the event that patients exhibited signs of clinical instability during the drug-free interval, prompt reinstitution of medication was initiated and these patients were not eligible for participation in this study. Data from eight of the subjects was previously reported (Breier et al. 1997).

Eight patients (age $=34.9 \pm 9.8$ years; seven males, one female) (length of illness $=10.8 \pm 8.8$ years) had 
evidence of mild TD, defined as Abnormal Involuntary Movement Scale (AIMS) (US Dept of Health 1976) scores greater than or equal to 14 (mean \pm SD: $15.5 \pm 1.3$ ). Six patients (age $=29.5 \pm 7.7$ years; four males, two females) (length of illness $=4.2 \pm 4.3$ years) showed no evidence of TD on AIMS ratings.

\section{Movement Ratings}

TD was assessed with the AIMS during the week of the PET scan, by a research psychiatrist (IE, CA). Interrater reliability coefficient was $>0.90$.

\section{Pharmacological Infusion Protocol}

Fifty minutes after commencement of raclopride administration (see below), a bolus of $0.2 \mathrm{mg} / \mathrm{kg}$ of amphetamine was administered as previously reported (Breier et al. 1997).

\section{PET Scanning Protocol}

Studies were conducted on a General Electric Advance scanner at the NIH Clinical Center as previously reported (Breier et al. 1997, 1998). Acquisitions were done with the interplane septa retracted and a wide axial acceptance angle. Each scan yielded 35 planes $4.25 \mathrm{~mm}$ apart. The effective resolution of the reconstructed images was $6 \mathrm{~mm}$ both axially and in-plane. Transmission scans were performed using two rotating ${ }^{68} \mathrm{Ge}$ sources and were used for attenuation correction.

Subjects were positioned in the scanner such that acquired planes would be parallel to the orbital-meatal line. Head movement was minimized with individually fitted thermoplastic masks. Patches were applied over the orbits to reduce incoming light. $\left[{ }^{11} \mathrm{C}\right]$ raclopride $(2.5$ to $8.0 \mathrm{mCi}$ ) was administered as a bolus followed by a constant infusion over 100 minutes. The bolus dose was $57 \%$ of the total amount administered. Beginning with the raclopride bolus, 27 scans were acquired over the 100 minute period. By infusing the $\left[{ }^{11} \mathrm{C}\right]$ raclopride, near-equilibrium conditions can be reached before administration of a pharmacologic agent, allowing a direct measurement of the binding potential from the ratio of striatum/cerebellum-1. In previous studies in monkeys, equivalent specific binding values were found using the conventional bolus methods and the bolus/infusion technique (Carson et al. 1997). Use of this bolus/infusion paradigm allows the measurement of baseline binding and change in dopamine concentration during a single scan without intrascan blood sampling (Carson et al. 1997). In addition, this paradigm facilitates interpretation of post-amphetamine changes in the curve (Endres et al. 1997).

\section{Image Data Processing and Analysis}

Image processing was performed with MIRAGE software developed by the NIH PET center and a single individual in a blinded fashion did all analyses. Images corresponding to $0-5$ minutes of raclopride infusion were added together to form a single "sum" image. Volumes of interest (VOIs) were drawn over the cerebellum and on the left and right striatum (caudate and putamen combined). After visual inspection, these VOI's were overlaid onto their corresponding position in each of the 31 individual scans and samples (mean pixel values) were generated for each VOI. Left and right striatal VOI's were averaged to a single striatal value. Specific binding was calculated as follows: striatum/cerebellum -1 .

Ratio data from five consecutive scans 30-50 minutes after the $\left[{ }^{11} \mathrm{C}\right]$ raclopride bolus injection and immediately prior to amphetamine administration ("baseline"), and five consecutive scans 75 to 100 minutes post$\left[{ }^{11} \mathrm{C}\right]$ raclopride bolus injection ("post-amphetamine") were calculated for all subjects ("change in specific binding").

\section{Data Analysis}

Baseline specific binding was compared between patients with an AIMS score of 10 (no TD) versus patients with an AIMS score of 14, using unpaired t-test. Change in specific binding with amphetamine administration was compared between groups using a one-way ANOVA. A follow-up unpaired t-test was also performed. Pearson's correlation coefficients were calculated between AIMS scores of 14 and both baseline specific binding and amphetamine-induced changes in specific binding. All comparisons were two-tailed.

\section{RESULTS}

Patients with AIMS scores of 14 demonstrated no significant difference versus patients without evidence of tardive dyskinesia in baseline binding $(\mathrm{t}=-0.64, \mathrm{df}=$ $12, p=.53)$. The effect size of the comparison was small to moderate $(\mathrm{d}=0.35)$. Including only schizophrenic and schizoaffective patients did not significantly alter these results $(\mathrm{t}=-0.88, \mathrm{df}=10, p=.40, \mathrm{df}=0.51)$.

Change in specific binding showed a significant effect for time, as expected ( $\mathrm{F}=18.49, \mathrm{df}=13, p<.001)$ but not for either group ( $\mathrm{F}=0.11, \mathrm{df}=13, p=.75)$ or group $\times$ time $(\mathrm{F}=0.04, \mathrm{df}=13, p=.85)$. The follow-up $\mathrm{t}$-test also showed no significant difference between cohorts $(\mathrm{t}=0.65, \mathrm{df}=12, p=.53)$. Effect size was small to moderate $(\mathrm{d}=0.35)$. Including only schizophrenic or schizoaffective patients did not significantly alter these results $(\mathrm{t}=0.71, \mathrm{df}=10, p=.49, \mathrm{~d}=0.42)$ (Figure 1$)$. 


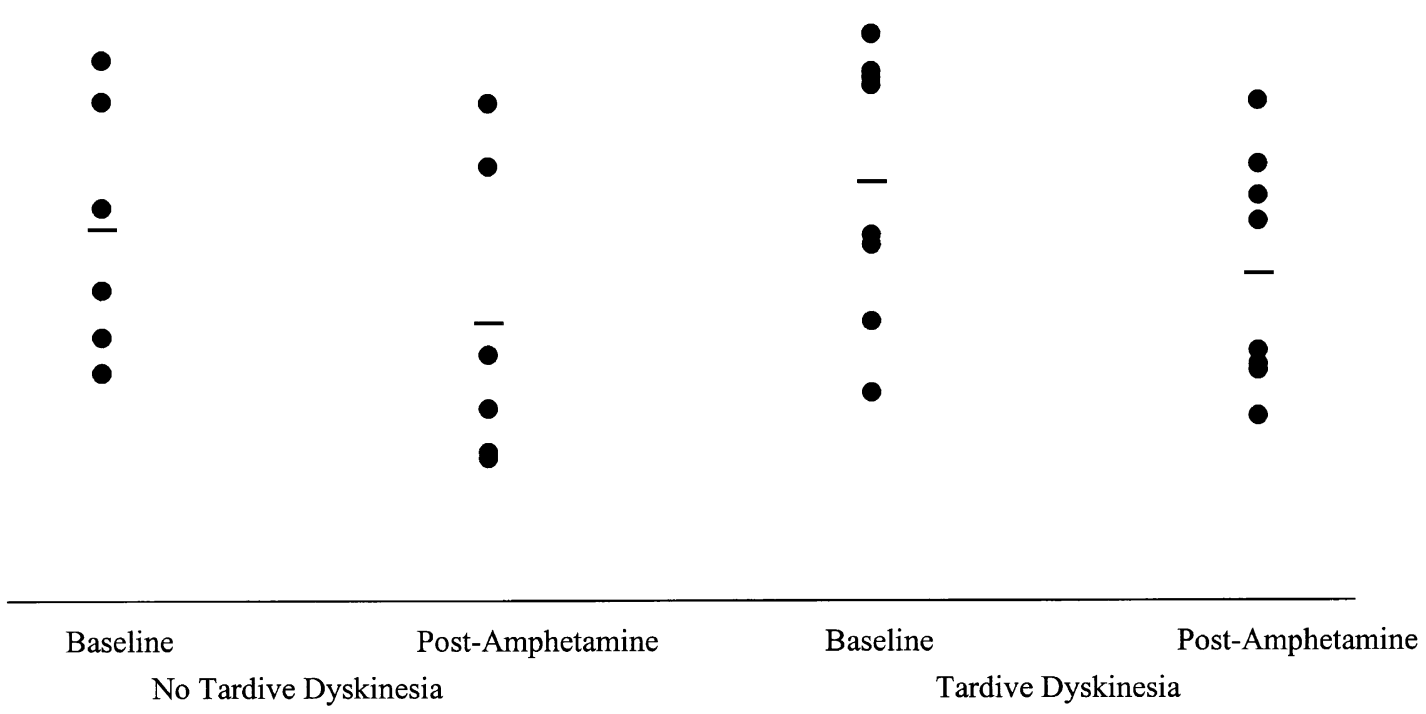

Figure 1. The effects of $\mathrm{d}$-amphetamine on $\left[{ }^{11} \mathrm{C}\right]$ raclopride striatal specific binding (striatum/cerebellum-1) in patients without evidence of tardive dyskinesia $(n=6)$ and patients with mild tardive dyskinesia $(n=8)$.

No significant correlations were found between AIMS scores of patients with TD and either baseline binding $(\mathrm{r}=0.13, p=.76)$ or change in specific binding $(\mathrm{r}=-0.31, p=.45)$. Excluding patients without diagnoses of schizophrenia or schizoaffective disorder did not significantly affect correlation coefficients for baseline binding $(\mathrm{r}=0.09, p=.85)$ or change in specific binding $(\mathrm{r}=-0.28, p=.55)$.

\section{DISCUSSION}

This study did not demonstrate an association between elevated AIMS scores and either increased striatal $D_{2}$ receptor binding or altered sensitivity to amphetamineinduced dopamine release. Neither baseline striatal $D_{2}$ receptor binding or the degree of change in specific binding significantly correlated with individual AIMS scores.

The results of this study are consistent with other PET and post-mortem studies that failed to observe an association between TD and striatal dopamine binding. Other studies of similar dyskinesias, such as that observed in patients with Parkinson's disease, have also failed to observe differences in striatal dopamine binding (Brooks et al. 2000). While several studies have observed evidence of basal ganglia pathology, our findings, as well as previous studies, fail to demonstrate any differences in endogenous dopamine concentrations or $\mathrm{D}_{2}$ specific binding that might underlie the pathogenesis of TD.

Similarly, preclinical studies demonstrating increased $D_{2}$ binding sensitivity with exposure to $D_{2}$ receptor antagonists are not fully consistent with clinical observations of TD. Increased dopamine sensitivity manifests rapidly in animals receiving dopamineblocking agents (Tarsy and Baldessarini 1974; Gianutsos and Moore 1977; Burt et al. 1977). In contrast, TD rarely appears without a considerably longer period of neuroleptic exposure (Jimenez-Jimenez et al. 1997). In addition, although dopamine sensitivity drops off rapidly after discontinuation of dopamine blocking agents in animals, TD may persist indefinitely even after administration of neuroleptic medications has been discontinued.

Several caveats need to be considered in interpreting our data. Sample sizes were relatively small, an issue with regard to interpreting our negative data. Nonetheless, effect sizes with and without inclusion of nonschizophrenic or schizoaffective patients were small to moderate, suggesting that larger cohorts would be unlikely to significantly alter our findings.

While the AIMS ratings of the patient group with TD were fairly low, all subjects in this group met at minimum the criteria of Schooler and Kane (1982) for "probable tardive dyskinesia." A diagnosis of "persistent tardive dyskinesia" could not be made in some cases because the patient was not evaluated over a full three months. Moreover, while mild, the movement symptoms observed in our affected group were clearly pathological.

Subjects in our study without evidence of TD tended to be both younger and to have been diagnosed with illness for a shorter period of time. While in neither instance are the differences statistically significant, age related changes in specific binding might partially obscure group differences (Wong et al. 1997; Volkow et al. 1998). While the lack of difference in baseline and change in specific binding we observed is sufficiently robust to make significant effects of subject age or years 
of illness unlikely, more age-matched cohorts will be recruited in future studies.

The data from this study adds further evidence to suggestions that hypotheses linking TD to increased dopamine binding sensitivity constitute an oversimplification, and by extension lend support to hypotheses suggesting other possible etiologies (Casey 2000). By not demonstrating any connection between $\mathrm{D}_{2}$ receptor binding and elevations in AIMS scores, this study suggests that further focus on related pathways and receptor systems might be necessary to yield a clearer understanding of the link between $\mathrm{D}_{2}$ receptor antagonists and TD.

\section{REFERENCES}

Adler CM, Elman I, Weisenfeld N, Kestler L, Pickar D, Breier A (2000) Effects of acute metabolic stress on striatal dopamine release in healthy volunteers. Neuropsychopharmacology 22(5):545-550

Andersson U, Eckernas SA, Hartvig P, Ulin J, Langstrom B, Haggstrom JE (1990): Striatal binding of 11C-NMSP studied with positron emission tomography in patients with persistent tardive dyskinesia: No evidence for altered dopamine D2 receptor binding. J Neural Transm Gen Sect 79(3):215-226

Blin J, Baron JC, Cambon H, Bonnet AM, Dubois B, Loc'h C, Maziere B, Agid Y (1989): Striatal dopamine D2 receptors in tardive dyskinesia: PET study. J Neurol Neurosurg Psychiatry 52(11):1248-1252

Breier A, Adler CM, Weisenfeld N, Su T-P, Elman I, Picken L, Malhotra AK, Pickar D (1998): Effects of NMDA antagonism on striatal dopamine release in healthy subjects: Application of a novel PET approach. Synapse 29:142-147

Breier A, Su T-P, Saunders R, Carson RE, Kolachana BS, de Bartolomeis A, Weinberger DR, Weisenfeld N, Malhotra AK, Eckelman WC, Pickar D (1997): Schizophrenia is associated with elevated amphetamine-induced synaptic dopamine concentrations: Evidence from a novel positron emission tomography method. Proc Natl Acad Sci U S A 94:2569-2574

Brooks DJ, Piccini P, Turjanski N, Samuel M (2000): Neuroimaging of dyskinesia. Ann Neurol 47(Suppl 1):S154S158

Burt DR, Creese I, Snyder SH (1977): Antischizophrenic drugs: Chronic treatment elevates dopamine receptor binding in brain. Science 196(4287):326-328

Campbell WG, Raskind MA, Gordon T, Shaw CM (1985): Iron pigment in the brain of a man with tardive dyskinesia. Am J Psychiatry 142(3):364-365

Cardoso F, Jankovic (1997): J Dystonia and dyskinesia. Psychiatr Clin North Am 20(4):821-838

Carson RE, Breier A, de Bartolomeis A, Saunders RC, Su TP, Schmall B, Der MG, Pickar D, Eckelman WC (1997): Quantification of amphetamine-induced changes in [11C]raclopride binding with continuous infusion. J Cereb Blood Flow Metab 17:437-447
Casey DE (1997): Will the new antipsychotics bring hope of reducing the risk of developing extrapyramidal syndromes and tardive dyskinesia? Int Clin Psychopharmacol 12(Suppl 1):S19-S27

Casey DE (2000): Tardive dyskinesia: Pathophysiology and animal models. J Clin Psychiatry 61(Suppl 4):5-9

Clow A, Jenner P, Marsden CD (1978): Supersensitivity of cerebral dopamine receptors during on-going chronic (six months) administration of trifluoperazine to rats. $\mathrm{Br}$ J Pharmacol 64(3):414P

Clow A, Jenner P, Theodorou A, Marsden CD (1979): Striatal dopamine receptors become supersensitive while rats are given trifluoperazine for six months. Nature 278(5699):59-61

Crane GE, Naranjo ER (1971): Motor disorders induced by neuroleptics: A proposed new classification. Arch Gen Psychiatry 24(2):179-184

Cross AJ, Crow TJ, Ferrier IN, Johnson JA, Johnstone EC, Owen F, Owens DG, Poulter M (1985): Chemical and structural changes in the brain in patients with movement disorder. Psychopharmacology Suppl 2:104-110

Endres CJ, Kolachana BS, Saunders RC, Su T, Weinberger D, Breier A, Eckelman WC, Carson RE (1997): Kinetic modeling of [11C]raclopride: Combined PET-microdialysis studies. J Cereb Blood Flow Metab 17:932-942

First MB, Spitzer RL, Gibbon M, Williams JBW (1997): Structured Clinical Interview for DSM-IV Axis I Disorders Patient Edition (SCID-I/P, Version 2.0, 4/97 Revision). New York, New York, Biometrics Research Department, New York State Psychiatric Institute

Gianutsos G, Moore KE (1977): Dopaminergic supersensitivity in striatum and olfactory tubercle following chronic administration of haloperidol or clozapine. Life Sci 20(9):1585-1591

Grace AA (1991): Phasic versus tonic dopamine release and the modulation of dopamine system responsivity: A hypothesis for the etiology of schizophrenia. Neuroscience $41(1): 1-24$

Granholm E, Bartzokis G, Asarnow RF, Marder SR (1993): Preliminary associations between motor procedural learning, basal ganglia $\mathrm{T} 2$ relaxation times, and tardive dyskinesia in schizophrenia. Psychiatry Res 50(1):33-44

Jeste DV, Caligiuri MP (1993): Tardive dyskinesia. Schizophr Bull 19(2):303-315

Jimenez-Jimenez FJ, Garcia-Ruiz PJ, Molina JA (1997): Druginduced movement disorders. Drug Saf Mar 16(3):180-204

Kane JM, Smith JM (1982): Tardive dyskinesia: Prevalence and risk factors, 1959 to 1979. Arch Gen Psychiatry 39(4):473-481

Klawans HL Jr (1973): The pharmacology of tardive dyskinesias. Am J Psychiatry 130(1):82-86

Kornhuber J, Riederer P, Reynolds GP, Beckmann H, Jellinger K, Gabriel E (1989): 3H-spiperone binding sites in post-mortem brains from schizophrenic patients: Relationship to neuroleptic drug treatment, abnormal movements, and positive symptoms. J Neural Transm 75(1):1-10

Meltzer HY (1989): Clinical studies on the mechanism of action of clozapine: The dopamine-serotonin hypothesis of schizophrenia. Psychopharmacology (Berl) 99(Suppl):S18-S27 
Meltzer HY, Gudelsky GA (1992): Dopaminergic and serotonergic effects of clozapine. Implications for a unique clinical profile. Arzneimittelforschung 42(2A):268-272

Mion CC, Andreasen NC, Arndt S, Swayze VW 2d, Cohen GA (1991): MRI abnormalities in tardive dyskinesia. Psychiatry Res 40(3):157-166

Morgenstern H, Glazer (1993): WM Identifying risk factors for tardive dyskinesia among long-term outpatients maintained with neuroleptic medications. Results of the Yale Tardive Dyskinesia Study. Arch Gen Psychiatry 50(9):723-733

Owen F, Cross AJ, Waddington JL, Poulter M, Gamble SJ, Crow TJ (1980): Dopamine-mediated behaviour and $3 \mathrm{H}$-spiperone binding to striatal membranes in rats after nine months haloperidol administration. Life Sci 26(1):55-59

Schooler NR, Kane JM (1982): Research diagnoses for tardive dyskinesia. Arch Gen Psychiatry 39(4):486-487

Silvestri S, Seeman MV, Negrete JC, Houle S, Shammi CM, Remington GJ, Kapur S, Zipursky RB, Wilson AA, Christensen BK, Seeman P (2000): Increased dopamine D2 receptor binding after long-term treatment with antipsychotics in humans: A clinical PET study. Psychopharmacology 152(2):174-180

Smith GS, Schloesser R, Brodie JD, Dewey SL, Logan J, Vitkun SA, Simkowitz P, Hurley A, Cooper T, Volkow ND, Cancro R (1998): Glutamate modulation of dopamine measured in vivo with positron emission tomography
(PET) and 11C-raclopride in normal human subjects. Neuropsychopharmacology 18:18-25

Spitzer RL, Williams JBW, Gibbon M, First MB (1990): Structured Clinical Interview for DSM-III-R - Patient Edition (SCID-P, Version 1.0). Washington, DC, American Psychiatric Press

Tarsy D, Baldessarini RJ (1974): Behavioural supersensitivity to apomorphine following chronic treatment with drugs which interfere with the synaptic function of catecholamines. Neuropharmacology 13(10-11):927-940

Turjanski N, Lees AJ, Brooks DJ (1997): In vivo studies on striatal dopamine D1 and D2 site binding in L-dopatreated Parkinson's disease patients with and without dyskinesias. Neurology 49(3):717-723

US Dept of Health (1976): ECDEU Assessment Manual for Psychopharmacology (Publication ADMA 76-338 AIMS, Revised Edition). Rockville, MD, US Dept of Health, Education and Welfare, pp 532-535

Volkow ND, Wang GJ, Fowler JS, Ding YS, Gur RC, Gatley J, Logan J, Moberg PJ, Hitzemann R, Smith G, Pappas N (1998): Parallel loss of presynaptic and postsynaptic dopamine markers in normal aging. Ann Neurol 44(1): 143-147

Wong WF, Pearlson GD, Tune LE, Young LT, Meltzer CC, Dannals RF, Ravert HT, Reith J, Kuhar MJ, Gjedde A (1997): Quantification of neuroreceptors in the living human brain. IV. Effect of aging and elevations of D2like receptors in schizophrenia and bipolar illness. J Cereb Blood Flow Metab 17(3):331-342 